\title{
ВЗАИМОСВЯЗЬ АЛЛЕЛЬНЫХ ВАРИАНТОВ ГЕНОВ СЕРОТОНИНЕРГИЧЕСКОЙ СИСТЕМЫ С УРОВНЕМ ТРЕВОЖНОСТИ У СТУДЕНТОВ
}

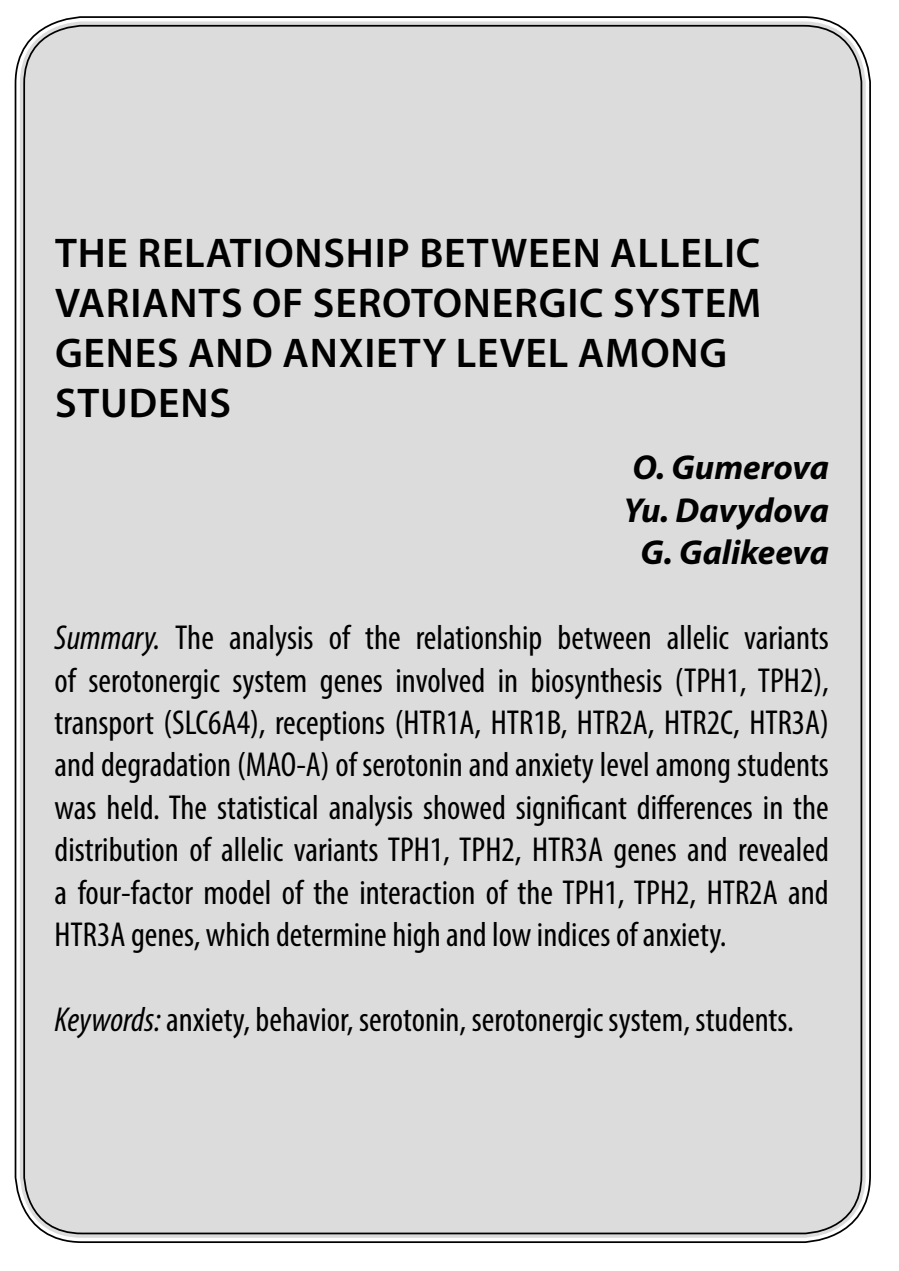

B ажнейшей составляющей успешной учебной деятельности студента является психологическая адаптация к стрессовым ситуациям. Тревожность рассматривается как один из ключевых показателей, определяющих эмоциональную устойчивость индивида [1], и включающий в себя как физиологические, так и поведенческие проявления. К основным физиологическим проявлениям относят усиление сердцебиения, учащение дыхания, повышение артериального давления и др. На поведенческом уровне тревога наблюдается как напряжение, нервозность и ощущение безобъективного страха. Имеются данные, что при длительном воздействии высокой тревоги происходят адаптивные перестройки систем организма, которые могут быть крайне тяжелыми и неблагоприятными для здоровья человека. В многочисленных исследованиях указывается
Гумерова Оксана Владимировна

К.б.н., дочент, ФГБОУВО «Башкирский государственный педагогический университет» (Уфа) gumerova_80@mail.ru

Давыдова Юлия Дмитриевна Аспирант, Институт биохимии и генетики УФИЦ PAH (Усpa)

julia.dmitrieva@list.ru

Галикеева Гузель Фанилевна

К.б.н., дочент, ФГБОУВО «Башкирский государственный педагогический университет» (Уфра) galikeevagf@yandex.ru

Аннотация. Проведен анализ взаимосвязи аллельных вариантов генов серотонинергической системы, участвующих в биосинтезе (ТPH1, TPH2), переносе (SLC6A4), рецепции (HTR1A, HTR1B, HTR2A, HTR2C, HTR3A) и деградации (МАО-А) серотонина, суровнем тревожности у студентов. Статистический анализ выявил достоверные различия в распределении аллелей генов TPH1, TPH2, HTR3A, а также четырёхфакторную модель взаимодействия генов TPH1, TPH2, HTR2A, HTR3А, определяющих высокие и низкие показатели тревожности.

Ключевые слова: тревожность, поведение, серотонин, серотонинергическая система, студенты.

на изменения в системе крови под действием тревоги, ослабление иммунитета, на повышенный риск развития вегето-сосудистой дистонии, гипертиреоза, тахикардии и ряда других патологических состояний [2].

В последние десятилетия в изучении эпидемиологии тревожности всё большее значение приобретают молекулярно-генетические исследования, которые свидетельствуют о том, что тревожность - это мультифакторный и генетически обусловленный признак, ключевая роль в котором отводится генам, участвующим в нейромедиаторном обмене.

Серотонинергическая система является важным регулятором поведения и эмоциональных характеристик человека, в том числе агрессивности, депрессивности, 
суицидального поведения, определяющих индивидуальную устойчивость к стрессу и адаптивные возможности человека [3].

На сегодняшний день предполагается, что активность генов, вовлечённых в процессы биосинтеза (ферменты триптофангидроксилаза-1 TPH1 и триптофангидроксилаза-2 TPH2), переноса (ген переносчика серотонина SLC6A4), рецепции (рецепторы HTRIA, $H T R 1 B, H T R 2 A, H T R 2 C, H T R 3 A$ ) и деградации (фермент моноаминоксидаза-А $M A O-A$ ) серотонина, может влиять на психологический статус индивида и, в том числе, на уровень его тревожности $[3,4,5,6]$.

Большинство работ по выявлению связи полиморфных вариантов генов с определенными психологическими характеристиками проводится на людях с различными психологическими расстройствами в целях поиска генетических основ заболевания. Однако, для формирования полной картины о наследуемости признака подобных исследований недостаточно. Исходя из этого, актуальным представляется исследование влияния генов серотонинергической системы и их полиморфных вариантов на уровень тревожности в группе студентов, у которых отсутствуют психические расстройства.

\section{Цель работы}

Исследование аллельных вариантов генов, отвечающих за биосинтез, перенос, рецепцию и деградацию серотонина, в выборке студентов с различным уровнем тревожности.

\section{Метолика исслеАования}

В исследовании приняли участие 223 студента БГПУ им. М. Акмуллы в возрасте 17-23 лет с информированного согласия на психологическое тестирование и сдачу биологического материала для проведения молекулярно-генетического анализа.

Оценку уровня личностной (ЛТ) и ситуативной (СТ) тревожности проводили с помощью методики самооценки Ч.Д. Спилбергера в адаптации Ю.Л. Ханина [7]. Сумма баллов, полученная в ходе тестирования, позволяла судить об уровне тревожности: до 30 баллов - низкий, 31-44 баллов - умеренный, 45 и более баллов высокий уровень тревожности.

Выделение ДНК проводилось из периферической крови с помощью метода фенольно-хлороформной экстракции [8]. Амплификацию изученных локусов проводили с помощью метода полимеразной цепной реакции (ПЦР) на амплификаторе «Терцик» в растворе объемом 10 мкл, содержащем 3,5 мкл Master Mix, 1,5 мкл $H_{2} 0,4$ мкл праймеров, 1 мкл ДНК. Разделение продуктов амплификации и рестрикции проводили в 7\% полиакриламидном геле.

Статистическую обработку данных проводили с помощью программ MS Excel 2016 (Microsoft) и GMDR (Generalized Multifactor-Dimensionality Reduction) для моделирования ген-генных и ген-средовых взаимодействий, а также таблиц сопряженности $2 \times 2$ (с поправкой Иэйтса).

\section{Результаты исслеАования и их обсужАение}

В ходе данного исследования была проанализирована гипотеза о влиянии аллелей генов серотонинергической системы на показатели тревожности у студентов.

Для проведения анализа вся выборка была разделена на 3 группы в соответствии с показателями тревожности [7]. Ситуативная и личностная тревожность анализировались отдельно.

В ходе исследования аллельных локусов девяти генов, отвечающих за биосинтез (A218C гена TPH1 и $G$-703T гена TPH2), перенос (HTTLPR гена SLC6A4), рецепцию (C-1019G гена $H T R 1 A, G 861 C$ гена $H T R 1 B$, $A-1438 G$ гена HTR $2 A, G 68 C$ гена HTR2C и C178T гена $H T R 3 A)$ и деградацию (EcoRV и Fnu4HI гена $M A O-A)$ серотонина, была выявлена корреляционная зависимость между полиморфными вариантами генов ТPH1, TPH2, HTR3A и уровнем ситуативной и личностной тревожности.

При анализе полиморфного локуса $A 218 C$ гена TPH1 выявлено статистически значимое повышение частоты аллеля * $A$ в группе лиц с высоким уровнем ситуативной тревожности $\left(\chi^{2}=4,3933 ; p=0,0363\right)$. Согласно литературным данным, наличие аллеля * $A$ приводит к повышению экспрессии гена TPH1 [5]. Исходя из этого, полученные результаты можно объяснить тем, что повышенная активность фермента tphl и высокая концентрация серотонина в синапсе, ведёт к усилению нервных процессов и определяет более высокие показатели тревожности.

Для полиморфного локуса $G$-703T гена $T P H 2$ установлено статистически значимое повышение частоты генотипа * $G /{ }^{*} G$ в группе с низким уровнем тревожности $\left(\chi^{2}=6,1813 ; \mathrm{p}=0,0136\right)$, а также частоты генотипа $* G / * T$

в группе со средними показателями СТ ( $\chi^{2}=7,8207$; $\mathrm{p}=0,0061)$. Известно, что триптофангидроксилаза-2 является ферментом, регулирующим (ингибирующим) биосинтез серотонина [6]. Результаты настоящего анализа, согласно которым частота генотипа ${ }^{*} G /{ }^{*} G$ выше у лиц 
с низким уровнем СТ, могут быть обусловлены тем, что высокоактивный аллель $* G$ определяет пониженную концентрацию серотонина и, следовательно, более низкие показатели тревожности.

При анализе полиморфного локуса C178T гена HTR3A было выявлено достоверное повышение частоты генотипа ${ }^{*} C / * C\left(\chi^{2}=6,7711 ; \mathrm{p}=0,0101\right)$ и аллеля ${ }^{*} C\left(\chi^{2}=3,8900 ; p=0,0486\right)$ в группе лиц с низким уровнем ЛТ, а также повышение частоты генотипа $* C / * T$ в группе лиц со средним уровнем ЛТ $\left(\chi^{2}=4,0468 ; p=0,0444\right)$. Полученные результаты согласуются с ранее проведёнными исследованиями других авторов, указывающих, что низкая рецепторная активность, обусловленная наличием низкоактивного аллеля $* C$, детерминирует более низкие показатели личностной тревожности [4].

В ходе статистического анализа была проведена оценка роли межгенных взаимодействий исследуемых локусов генов серотонинергической системы. C помощью программы GMDR была определена четырёхфакторная модель взаимодействия аллелей генов TPH1 (A218C), TPH2 (G-703T), HTR2A (A-1438G) и HTR3A (C178T), которая демонстрирует степень формирования различий по признаку «ситуативная тревожность». Тестируемая сбалансированная точность модели 0,8077; чувствительность - 0,7043; специфичность 0,9111; повторяемость - 10/10, $\mathrm{p}=0,0107$.

Было выявлено 5 комбинаций генотипов, определяющих высокие показатели по шкале СТ. Наиболее значимым оказалось сочетание генотипов $T P H 1 * A / * A+$ TPH $2 * G / * T+5-H T R 2 A * A / * A+5-H T R 3 A * C / * C$, в котором при взаимодействии аллелей $T P H 1 * A$ и $T P H 2 * T$, определяющих высокую скорость биосинтеза серотонина, а также компенсирующего взаимодействия аллелей 5-HTR $2 A * A$ и 5-HTR $3 A^{*} C$, определяющих высокий и низкий уровни рецепции соответственно, наблюдаются высокие показатели ситуативной тревожности.

При анализе сочетаний генотипов, определяющих низкие показатели, наиболее значимым оказалось сочетание $T P H 1{ }^{*} C /{ }^{*} C+T P H 2 * G /{ }^{*} G+H T R 2 A * A / * G$ $+H T R 3 A^{*} C / * C$. Полученный результат демонстрирует то, что при наличии аллелей $T P H 1 * C$ и $T P H 2 * G$, определяющих низкую скорость биосинтеза серотонина, и аллелей $H T R 2 A * G$ и $H T R 3 A * C$, определяющих низкий уровень рецепции, наблюдаются низкие показатели тревожности.

\section{Зак^ючение}

Таким образом, в результате данного исследования были выявлены достоверные ассоциации по генам $T P H 1, T P H 2$ и HTR3A с различиями по показателям ситуативной и личностной тревожности. Установлено, что у носителей аллеля *A гена $T P H 1$, определяющего повышение скорости биосинтеза серотонина, наблюдается повышение показателей ситуативной тревожности; у носителей аллеля ${ }^{*} G$ и генотипа ${ }^{*} G /{ }^{*} G$ гена $T P H 2$, определяющих пониженную скорость биосинтеза, а также аллеля *C и генотипа ${ }^{*} C /{ }^{*} C$ гена $H T R 3 A$, связанного с низкой рецепторной активностью, наблюдаются низкие показатели СТ и ЛТ соответственно.

Анализ межгенных взаимодействий позволил установить сочетания генотипов исследуемых генов TPH1, $T P H 2, H T R 2 A$ и HTR $3 A$, влияющих на различия по показателям тревожности. Было выявлено, что взаимодействие высокоактивных аллелей $T P H 1 * A$ и $T P H 2 * T$, участвующих в биосинтезе серотонина, и взаимодействия аллелей $H T R 2 A^{*} A$ и $H T R 3 A^{*} C$, определяющих высокий и низкий уровни рецепции соответственно, наблюдаются более высокие показатели, в то время как при взаимодействии низкоактивных аллелей $T P H{ }^{*} C$, $T P H 2 * G, H T R 2 A * G$ и $H T R 3 A * C$ наблюдаются низкие показатели тревожности.

Выявленные закономерности согласуются с существующей в настоящее время гипотезой о серотониновой регуляции тревожности, в соответствии с которой усиление активности серотонинергической системы сопровождается усилением тревожности, а также позволяют приблизиться к пониманию молекулярно-генетических основ данной поведенческой характеристики и открывают перспективы для успешного прогнозирования и коррекции с целью повышения качества жизни индивидов.

\section{ЛИТЕРАТУРА}

1. Сидоров К. Р. Тревожность как психологический феномен // Вестник УдГУ. 2013. - Вып.2. - C. 42-52.

2. Галямина А. Г. Исследование взаимосвязи депрессии и тревожности в развитии смешанного тревожно-депрессивного расстройства: фармакологический подход: автореф. дис. . . канд. биол. наук // Новосибирск, 2015. - 18 с.

3. Колесникова Л.И., Долгих В. В., Гомбоева А.С. Гены нейромедиаторных систем и психоэмоциональные свойства человека: серотонинергическая система // Бюллетень ВСНЦ СО РАМН. 2011.— № 5.—C. 212-215.

4. Niesler B., Flohr T., Nöthen M. Association between the 5'UTR variant C178T of the serotonin receptor gene HTR3A and bipolar affective disorder // Pharmacogenetics. 2001.— № 11(6).—P.471-475. 
5. Левчук Л.А., Шмиголь М. В., Иванова С. А. Серотонинергическая система в патогенезе и терапии депрессивных расстройств // Сибирский вестник психиатрии и наркологии. - 2012. - № 2(71).- - С. 75-79.

6. Чуканова А. С. Клинико-генетические аспекты побочных эффектов топирамата у больных эпилепсией: автореф. дис. .. канд. мед. наук // Москва, 2011. $26 \mathrm{c}$.

7. Барканова О. В. Методики диагностики эмоциональной сферы: психологический практикум // Красноярск: Литера-принт, 2009. - С. $215-222$.

8. Mathew C.C. The isolation of high molecular weight eucariotic DNA // Methods in Molecular Biology. 1984. — V.2. — P. 31-34.

( Г Гумерова Оксана Владимировна ( gumerova_80@mail.ru),

Давыдова Юлия Дмитриевна ( julia.dmitrieva@list.ru ), Галикеева Гузель Фанилевна ( galikeevagf@yandex.ru ).

Журнал «Современная наука: актуальные проблемы теории и практики»

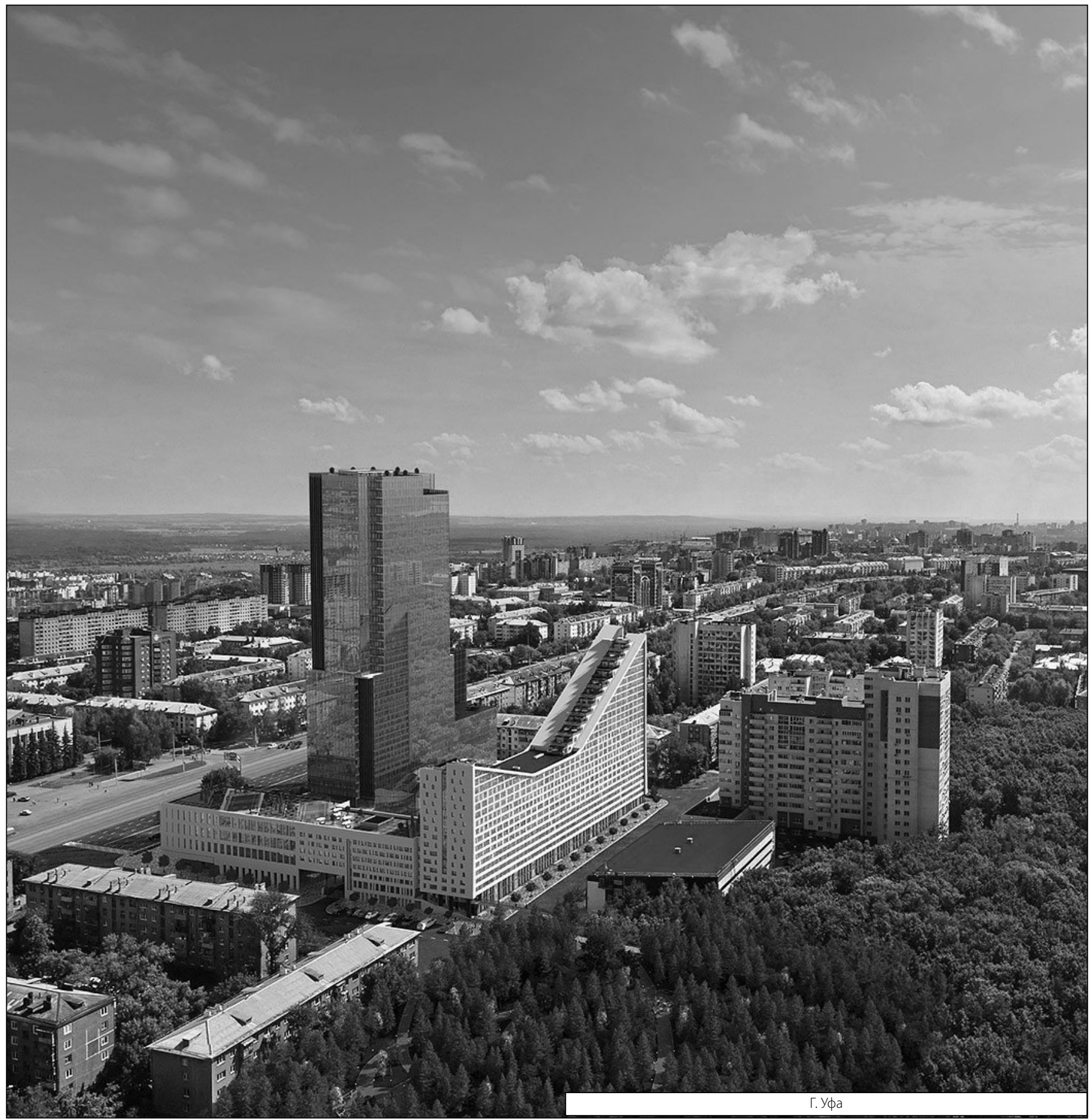

